\title{
Efficacy of Monitoring and Evaluation Function in Achieving Project Success in Kenya: A Conceptual Framework
}

\author{
Charles G. Kamau, Humam Bin Mohamed \\ Faculty of Finance \& Administrative sciences, Almadinah International University, Shah Alam, Malaysia
}

Email address:

guandaruman@yahoo.co.uk (C. G. Kamau),mohamedhumam@yahoo.co.uk (H. B. Mohamed)

\section{To cite this article:}

Charles G. Kamau, Humam Bin Mohamed. Efficacy of Monitoring and Evaluation Function in Achieving Project Success in Kenya: A Conceptual Framework. Science Journal of Business and Management. Vol. 3, No. 3, 2015, pp. 82-94. doi: 10.11648/j.sjbm.20150303.14

\begin{abstract}
This paper sets out to review literature on the efficacy of monitoring and evaluation in achieving project success in Kenya. Several studies have been carried out with an aim of determining the critical success factors (CSFs) which contribute to project success. The analysis of these studies shows a particular pattern of events. Some CSFs appears consistently in a number of studies. One such factor is the monitoring and evaluation (M\&E) function. The researcher used literature review approach to analyze the factors related to M\&E influencing project success. All the factors identified were grouped into four main categories which are: Strength of M\&E team, monitoring approach adopted, political influence and project lifecycle stage. The study further identified management support as a mediating factor between M\&E and the Project Success. A good M\&E without management support is likely not to succeed.
\end{abstract}

Keywords: Monitoring and Evaluation, Project Success, Conceptual Framework, Management Support, Kenya

\section{Introduction}

\subsection{Relationship between M\&E and Project Success}

Several studies have been carried out with an aim of determining the critical success factors (CSFs) which contribute to project success. Most of the studies as discussed in the following paragraphs links project success to M\&E. The problem of this study is that, despite knowledge that effective $\mathrm{M} \& \mathrm{E}$ is a major contributor to project success, there are still project failures in Kenya. This section explores the existing knowledge that links effective M\&E to project success.

A study by Prabhakar (2008) pointed that Monitoring and Feedback was one of factors leading to project success. Likewise Papke-Shields et' al (2010) also noted that the probability of achieving project success seemed to be enhanced among other factors, by constantly monitoring the progress of the project. According to their study, monitoring and controlling was relevant in management of project scope, time, cost, quality, human resources, communication and risks.

In agreement, Hwang and Lim (2013) also established that Monitoring and evaluating, budget performance, schedule performance and quality performance could lead to project success. Ika et' al (2012) carried out a regression analysis which shows that there was a statistically significant and positive relationship between each of the five Critical Success Factors and project success. The five critical success factors include monitoring, coordination, design, training and Institutional environment. He further explained that, consistent with theory and practice, the most prominent CSFs for project supervisors are design and monitoring. Hence Ika et' al (2012) ranks M\&E highly as one of the major project success factors.

A research carried out by Ika et' al (2010) established that project success was insensitive to the level of project planning efforts but on the other hand ascertained that a significant correlation does exist between the use of monitoring and evaluation tools and project "profile," a success criterion which was an early pointer of project long-term impact. Once again Ika et' al (2010) accentuates that M\&E is even more critical than planning in achievement of project success. Similarly one of the components of the project management methodology whose main aim is to achieve project success was monitoring project progress (Chin, 2012).

There seems to be consensuses across the project management field of study in the statement that monitoring and evaluation is a major contributor to project success. To crown it all, PMBOK (2001) which is a book which presents a set of standard guidelines which are widely accepted and consistently applied, continually stresses the importance of monitoring and evaluation in achieving project success. 


\subsection{Problem Statement}

The success of projects plays a key role in achieving organization growth and development. Most project managers appreciate that monitoring and evaluation of projects is important if the project objectives and success is to be achieved. Project monitoring and evaluation exercise adds value to the overall efficiency of project planning, management and implementation by offering corrective action to the variances from the expected standard. "Project managers are required to undertake more rigorous monitoring and evaluation of the projects and develop frameworks and guidelines for measuring impact" (Kahilu, 2010). By so doing they will achieve greater value creation for the organization through project success.

Studies carried out in Kenya shows that quite a number of projects have been successful. For example, The Youth Enterprise Development Fund; whose objective was to increase economic opportunities for the youth as a way of enabling them to participate in nation building (Kimando, 2012); the self reliant agriculture (SRA) projects which were meant to help the villagers become self reliant by growing their own food. This program was viewed as successful since it realized its goals through training local population of Mnyenzeni on how to raise their own food. Most of the villagers had access to land where they could plant gardens and raise animals but the land was not used efficiently (Ward, 2010). On the other hand, several projects in Kenya have been informally cited as failed projects; meaning that they did not achieve the desired success. Examples of such projects include the Kibera slum upgrading project, the Lake Turkana fish processing plant project, The Anglo-leasing ICT related projects, Modambogo Health Center in rain water harvesting Mwatate, and Tumaini Women Self Help group project in Kisumu among others. Some of the studies show that one of the drawbacks of monitoring and evaluation in Kenya is failure by the management to implement the recommendations offered by the M\&E team (Ochieng et' al, 2012). In Africa including Kenya, project management is also complicated by some factors such as lack of skills in project management, political and community or societal demands.

A significant share of the failed projects was government funded or donor funded projects. These projects usually undergo the necessary monitoring and evaluation processes which are often a requirement of the law. The paradox is, despite a consensus among scholars that proper monitoring and evaluation leads to project success, there are still cases of project failure in Kenya. Further projects fail despite heavy presence of monitoring and evaluation activities. This therefore raises serious issues as to whether the monitoring and evaluation employed is effective enough to achieve project success. The monitoring team perhaps may be lacking the necessary capacity or strength to carry out their work effectively, or they may be approaching their work using incorrect methodologies. The project monitoring team may also be lacking the necessary management support. This thesis examined the efficacy of monitoring and evaluation in achieving project success in Kenya. The findings of the study attempted to provide a solution to the stated problem.

\section{Literature Review}

\subsection{Monitoring and Evaluation in Project Management}

PMBOK (2001) explains that monitoring and control of project work is "the process of tracking, reviewing, and regulating the progress to meet the performance objectives defined in the project management plan". It further explains that monitoring includes status reporting, progress measurement, and forecasting. Performance reports provide information on the project's performance with regard to scope, schedule, cost, resources, quality, and risk, which can be used as inputs to other processes.

Monitoring and evaluating of projects can be of great importance to various players including project sponsors as it would ensure similar projects are replicated elsewhere as witnessed in various projects undertaken by the financial sector which revolve around a few areas (Marangu, 2012).

Through the review of literature, the researcher singled out three major aspects in relation to monitoring and evaluation in project management. The three aspects include strength of the monitoring team, approaches to M\&E and stages in project lifecycle. These three aspects are explained in the subsequent paragraphs 2-3-2-1 Strength of the monitoring team

Naidoo (2011) noted that if the M\&E function is located in a section or associated with significant power in terms of decision-making, it is more likely to be taken seriously. $\mathrm{He}$ further explained that M\&E units want to be seen as adding value, and must for their own perpetuation be able to justify their efforts hence M\&E managers need success factors to bolster their credibility. This means that the monitoring team needs to be enhanced and strengthened in order for it to have more power which will increase its effectives. In addition to power of M\&E teams other factors also play a role in strengthening monitoring teams which includes: frequency of scope monitoring to identify changes, Number of persons monitoring project schedule, Extent of monitoring to detect cost over runs, (Ling et' al, 2009).

Magondu (2013) also noted that financial availability is the main resource in any functional organization as far as other resources such as human are concerned. To set up a monitoring department, finances are required. He further elucidates that staff capacity both in numbers and skills are also very instrumental in any effective implementation and sustainability of monitoring and evaluation. Without relevant skills it's hard to master the rule of any game. Therefore, the staffs need to be equipped with the relevant skills for performance and success.

Project structural capacity and in particular data systems and information systems are also necessary for monitoring and evaluation exercise (Hassan, 2013). An effective monitoring and evaluation is a major contributor to project success and hence the use of technology to compliment the efforts of the M\&E team will strengthen it; which will in turn lead to value 
addition by the team.

Managing Stakeholders, teamwork among members and monitoring the progress of the project work are some of the key processes used to manage the project work (Georgieva \& Allan, 2008). A good monitoring team is the one that has good stakeholders' representation. Likewise an M\&E team which embraces teamwork is a sign of strength and an ingredient for better project performance.

Gwadoya, (2012) found that there was a shared need for proper understanding of Monitoring \& Evaluation practices in donor funded projects. This is an indication that there was lack of shared understanding of Monitoring \& Evaluation practices in donor funded projects among the various teams. With proper enhancement and capacitating of the monitoring teams, there would be more team work and hence more productivity.

In summary the literature reviewed identified various issues which when applied appropriately would strengthen the monitoring team. These issues include: Financial availability, number of monitoring staff, monitoring staff skills, frequency of monitoring, Stakeholders representation, Information systems (Use of technology), Power of M \& E Team and teamwork.

\subsection{Monitoring and Evaluation Approaches}

Effectiveness of project monitoring and evaluation is also dependent on the approach of M\&E. There are various M\&E approaches that have been singled out through literature review. The M\&E approaches that have been identified from the literature are explained in the following paragraphs.

Stem et al (2005) established that some of the monitoring and evaluation approaches that may be applied by project managers and monitoring teams include: basic research; accounting and certification; status assessment; and effectiveness measurement. Alotaibi (2011) in his study discovered that Saudi Arabia lacked an appropriate construction contractor performance evaluation framework, and the identification and exploration criteria and sub-criteria for a selection framework. Lack of evaluation framework has a negative effect on the project success.

Mladenovic et' al (2013) also established a two layers approach for the assessment of Private-Public Partnership projects. The first stage was based on evaluation of project ultimate objectives from the standpoint of each stakeholder, i.e. profitability for private sector, effectiveness and value for money for public sector, and level of service for users.

The Balanced Scorecard is another approach that can be employed in evaluating projects. Balanced score card evaluates projects on the basis of four perspectives which are, the financial perspective, customer perspective, Internal Business Process, and Learning \&Growth. Alhyari et' al (2013) found out that balanced score card approach fitted very well with monitoring and measuring the performance of e-government in Jordan, and also in evaluating their success in IT project investments.

Logical framework (Log frame) is one of the most common approaches used in project management for both planning and monitoring of projects. Log frame matrix is a tool that is applicable for all organizations both government and nongovernmental that are engaged in development activities (Middleton, 2005; Martinez, 2011). Hummelbrunner, R. (2010) further confirms the continued use of Log frame despite several criticisms. He asserts that Log Frame's Approach has not been fundamentally weakened by critics. Even though many donors acknowledge its limits and weaknesses, they still maintain its use as a planning and monitoring tool. Myrick (2013) expresses that a pragmatic approach to M\&E is ideal however in the real world practitioners may be limited by constraints that will prevent their continued use of either a log frame or some overly pragmatic approach to M\&E. He further explains that whatever the approach used, at least the basic principles for $\mathrm{M} \& \mathrm{E}$ which are measureable objective, performance indicator, target and periodic reporting should be used in a reporting tool. The advantages of a Log frame include simplicity and efficiency in data collection, recording and reporting.

Other approaches include stochastic methods, Fuzzy logic model, and miscellaneous methods. Of all the methods, the Earned Value Analysis (EVA) has remarkable advantages in accuracy, flexibility, and adaptability for project complexity. This may have contributed to Malaysian government deciding to implement EVA to enhance the level of project management for the whole country (Abdul-Rahman, Wang, \& Muhammad, 2011).

A précis of literature regarding approaches to $M \& E$ in project management includes: basic research, accounting and certification, status assessment, effectiveness measurement, Objectives evaluation - value for money, Balanced Scorecard and Earned Value Analysis.

\subsection{Project Lifecycle Stages}

PMBOK (2001) describes project life cycle as the project phases and their relationship to each other and to the project, and includes an overview of organizational structure that can influence the project and the way the project is managed. The four stages are as illustrated in figure 1 below and they include: Starting the project (initiation), Organizing and preparing (planning), Carrying out the project work (execution), and Closing the project. PMBOK (2001) further advocates for constant monitoring and evaluation across all the four stages of the project lifecycle. 


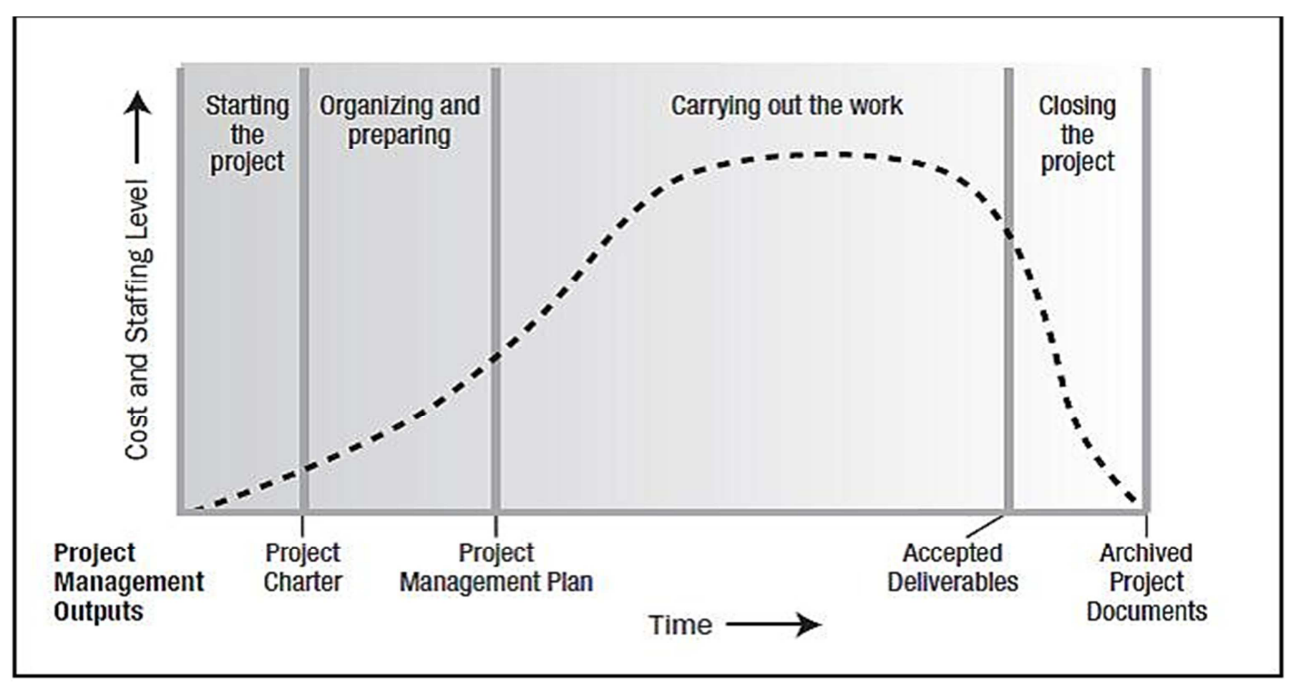

Fig. 1. Project life cycle (Source: PMBOK, 2001: p 16).

Fig 1 above clearly shows that each stage of project life cycle requires different effort from the management. In the same way each stage in the project life cycle requires different level of effort in terms of monitoring and evaluation.

Kyriakopoulos (2011) elucidates that it is important to carry out frequent monitoring and perform focused reviews involving all the stakeholders in keeping the project on tract. Reviewing progress and controlling the use of resources should be carried out on a regular basis. He stresses the importance of overall monitoring throughout the project initiation, implementation, staff education, and technical maintenance.

The components of the Project Management Methodology includes: project management processes such as initiating, planning, executing and monitoring project progress; a selection of tools and techniques to communicate delivery to the satisfaction of all stakeholders; consolidated and integrated set of appropriate best practices and values of project management and; a list of references of terminology as a common denominator and language for us in the project environment (Chin, 2012).

Many managers make the mistake of not involving members of their project teams in early planning and conceptual meetings, perhaps under the assumption that the team members should only concern themselves with their specific jobs (Pinto and Slevin, 1988). All project teams including M\&E should be involved in all the stages of the project lifecycle in order to achieve better success.

Müller and Turner's (2007) study was inconclusive in respect to project success in relation to project life cycle stage. This implies that more research may be necessary to have a closer look at project success and in relation to project life cycle stage. This is one of the gaps that this study seeks to address more so in relation to project monitoring and evaluation.

Research shows that project management plays a key role and hence a proper emphasis must be placed in selecting the project team that ensures proper decision making at various stages of project life cycle, and results in timely project completion and hence project success (Ara and Al-Mudimigh, 2011). The selection of project team includes the monitoring and evaluation team.

Study carried on international development projects in line with project life cycle framework confirmed the common perception of the development community that the implementation phase is when projects exhibit most problems. It was not surprising that after the implementation phase, the closing phase is less successful than the early stages of the project life cycle (Khang and Moe, 2008).

\subsection{Political influence on $M \& E$}

Kenya has a strong political culture which is ethnic based. Ethnic favoritism is one of the political strategies where the politicians manipulate the allocation of public expenditure with an aim of gaining mileage from the supporters. Since Kenya gained independence, there is a strong evidence of ethnic favoritism: districts that share the ethnicity of the politician receive substantial expenditure on projects such as roads where they get up to four times the length of paved roads built (Burgess et' al, 2013). Strong political support, together with a commitment to the smallholder sector for example, is at the heart of support of the dairy industry. Influential politicians have been enlisted as one of the key players in the success and failure of the daily industry in Kenya (Atieno, 2014).

Muriithi \& Crawford (2003) identified several issues related to approaches to project management in Africa, including the need to cope with political and community demands on project resources. Politics both in the organization and in the country is motivated by the scarcity of resources and the interests of the leaders. Generally in Africa a number of decisions are politically motivated.

Pinto (2000) advises that successful project management is directly linked to the ability of project managers and other key players to understand the importance of organizational politics and how to make them work for project success. Most of the people view politics with distaste; nevertheless effective managers are often those who are willing and able to employ 
appropriate political tactics to further their project goals.

All aspects of the project are reviewed during the project appraisal stage in order that the decision on whether or not to proceed can be made. One of the criteria that should be used in developing countries is the political impacts on the project (Cusworth and Franks, 2013). During monitoring and evaluation phase, political influence should also be reviewed so as to determine whether the project will continue or not.

Politicians use the sacred cow model as one of the entry points in attempt to control projects. The Sacred Cow Model involves a situation where a project is identified and suggested by a senior and powerful individual in an organization. These models are used by government funded projects in developing countries partly because these governments earn political support from citizens based on the number and size of projects they undertake (Asaka et'al, 2012). The governors who are the CEOs of the county governments are elected by the citizens. There is therefore likelihood that most of them may use sacred cows model in identification of some major projects. Monitoring and evaluation of projects that have been selected in this manner may also face political influence which may ether positively or negatively affect the project success.

\subsection{Role of Management in M\&E and Project Success}

Management and leadership as well as project teams, is also emphasized in the literature as having a significant effect on the project success. Management and leadership also play a key role in supporting monitoring and evaluation of projects. Yang et' al (2011) carried out an analysis that suggested that increases in levels of leadership may enhance relationships among team members. The study also indicated that teamwork had a statistically significant influence on project performance.

Yang et'al (2009) analyzed the various factors which are critical to the success of a project most which were centered around managing stakeholders, Assessing attributes (power, urgency, and proximity) of stakeholders, Compromising conflicts among stakeholders effectively, Formulating a clear statement of project missions, Predicting stakeholders' reactions for implementing the strategies, Analyzing the change of stakeholders' influence \& relationships during the project process and Assessing stakeholders' behavior. Yang's critical success factors were mainly focused around the stakeholder's management. It's the role of management to look into the affairs of stakeholders. However stakeholder management is not the only responsibility of management as regards project success.

Research also shows that some of the best project management practices include: Managing Communications, Managing Stakeholders, Motivating, and Knowledge Transfer Planning, testing and monitoring the progress of the project work are some of the key processes used to manage the project work (Georgieva \& Allan, 2008).

Under normal circumstances the project managers implement any project as guided by government rules and regulations, organizations requirements, stakeholder's preferences and client location. It is important that management confirms the completion of promised deliverables. Performance during monitoring is compared against the original plans created during the first days of a project and measurements must be against revised and relevant baseline plans (Attarzadeh \& Ow, 2008). It is the role of management to facilitate monitoring and evaluation of the projects.

Management's competence, commitment to the project, communication and cooperation with the project teams has a significant contribution towards the success of a construction project. These factors were found to be of significance in as assessed in Malaysian construction industry (Yong \& Mustaffa, 2012). Management commitment is a key aspect when it comes to the implementation of monitoring and evaluation since they are key decision makers in an organization (Magondu, 2013).

Atencio (2012) suggested that charismatic leadership and people-oriented/relations-oriented leadership have negative connotations associated with them. Charismatic leaders are viewed as not having follow-through. People-oriented/relations-oriented leadership is viewed as biased and ineffective do to the subjectivity of the decisions made, and actions taken that are heavily influenced by favorable relationships. This implies that the leadership style adopted by the management has an effect on the performance of project teams.

Jetu \& Riedl, (2013) pointed out that, personally focused cultural values, such as openness to change, rather than socially focused cultural values, such as self-transcendence have the most significant influence on project team performance. They further found cultural values to have a strong relationship with two out of three dimensions of Project Team Success, namely, project team learning and development, as well as project team working spirit, when compared to project team leadership.

Community participation right from the onset of the project is critical as it ensures that the community owns up the project which is viewed as one of the factors that could ensure project success (Marangu, 2012). It is the role of management to ensure that there is community participation and in fact participation of all the stakeholders in the project implementation and in monitoring so as to guarantee project success.

Muriithi \& Crawford (2003) identified several issues related to approaches to project management in Africa. These issues include: the need to cope with political and community demands on project resources, recognition that economic rationality and efficiency, assumed as a basis for many project management tools and techniques does not reflect local realities; and that use of such tools and techniques will not enhance project success if they run counter to cultural and work values.

In summary management has a role in enhancing project success through supporting monitoring and evaluation team. Such support may be achieved through factors such as Communication, Commitment, Leadership Style, Managing politics, Managing societal demands and Motivation. 
Management of projects in Africa faces some challenges such as political interference and strong societal demands.

\subsection{Research Gaps}

There have been a number of valuable studies of Project success, majority of which seems to agree that monitoring and evaluation is a major contributor to project success (Prabhakar, 2008; Papke-Shields et' al, 2010; Hwang and Lim, 2013; Ika et' al, 2012; Chin, 2012; Ika et' al, 2010).

Though the studies carried out mainly dealt with critical success factors, monitoring and evaluation being one of them, few of the studies have focused on monitoring and evaluation in isolation and in a greater detail. Several other studies reviewed also focused on monitoring and evaluation for example (Peterson and Fischer, 2009: Naidoo, 2011; Mwala, 2012; Marangu, 2012; Ling et' al, 2009) but none have addressed to the specific link between monitoring and evaluation in relation to project success. This is the first gap that this study seeks to address.

Several studies in the literature reviewed brought out three main aspects of monitoring and evaluation in project management. The first of these aspects is strength of M\&E team (Naidoo, 2011; Ling et' al, 2009; Magondu, 2013; Hassan, 2013; Georgieva \& Allan, 2008; Gwadoya, 2012), the second aspect being M\&E approaches (Stem et al, 2005; Alotaibi, 2011; Mladenovic et' al, 2013; Alhyari et' al, 2013; Abdul-Rahman, Wang, \& Muhammad, 2011), and the third being project lifecycle stages (Kyriakopoulos, 2011; Chin, 2012; Pinto and Slevin, 1988; Müller and Turner, 2007; Khang and Moe, 2008). The researcher did not come across a research which combined all the three aspects identified that is strength of M\&E team, M\&E approach and project life cycle stage. This is the second gap that this research addressed. The study will look into the effect of M\&E team, M\&E approach and project life cycle stage on project success. The research will also look at M\&E within the framework of the project lifecycle.

In Africa and developing countries, including Kenya, political influence plays a major role in project management, more so in the public sector (Atieno, 2017; Muriithi \& Crawford, 2003; Pinto, 2000). One of the models that is employed by the politicians in controlling projects is the sacred cow model where the politician or a powerful person in the organization dictates on the projects to be implemented (Asaka et'al, 2012). Political influence is to be expected in project management and this includes monitoring and evaluation aspect. The researcher did not come across studies that have covered the effect of political influence on monitoring and evaluation and how it affects the project success. This is yet another gap that this study sought to address.

The review of literature suggests that there are researches that have been carried out mostly from USA, Malaysia, Iran, India, Nigeria, United Kingdom, and the like. Not much of the studies have been carried out on the monitoring and evaluation in relation to project success from a Kenya's perspective. The few that have been carried out have not focused into monitoring and evaluation as a key project success factor (Hassan, 2013; Magondu, 2013; Marangu, 2012; Muriithi \& Crawford, 2003). Therefore another knowledge gap that was addressed by this study in an attempt to add to the body of knowledge is to give the research a Kenyan perspective.

\section{Discussion of Variables}

\subsection{Project Success}

PMBOK (2001) explains that project success is measured by product and project quality, timeliness, budget compliance, and degree of customer satisfaction. Ling et'al (2009) also assessed Scope management, Time management, Cost management, Quality management, Risk management, Human resource management, Procurement management, and Integration management in relation to project success where he established the there were significant associations. These factors were closer to Papke-Shields' (2010) factors.

Time dimension of assessing project success is the most common aspect brought out in the literature review. Pretorius et' al (2012) found out that project management organizations with mature time management practices produce more successful projects than project management organizations with less mature time management practices. Project time is the absolute time that is calculated as the number of days/weeks from start on site to practical completion of the project. Speed of project implementation is the relative time (Chan, 2001). Peterson \& Fisher (2009) established that construction firms are usually interested in monitoring project time variance and verifying contractor progress payments requests. Kariungi (2014) expressed that energy sector projects were completed on time due to factors such as efficient procurement procedures, favorable climatic factors, timely availability of funds and proper utilization of project planning tools.

Completion of the project within the budget is another dimension that is used to measure project success. Costs can be computed in form of unit cost, percentage of net variation over final cost and so on (Chan, 2001). The project monitoring and evaluation team may control the costs using PERT and CPM techniques. Projects often face cost overruns during the implementation phase; hence a proactive approach is essential for monitoring project costs and detection of potential problems (Cheng et'al, 2012). Related to cost aspect of measuring project success, is technical performance. Baker et' al (2008) identified technical performance as one of the project success factors among others such as schedule performance and cost performance. Quality achievement by projects is also another dimension of assessing project success The quality of projects and project information has a significant influence project success (Raymond \& Bergeron, 2008). Closely related to the quality and technical requirement dimensions is the scope. Project completion within scope is considered as one of the success factor. The project charter or statement of work requires the implementers to develop a scope of work that was achievable in a specified period and 
that contained achievable objectives and milestones (Bredillet, 2009).

Another important dimension in project success includes customer satisfaction (Dvir, 2005). A project that in the final analysis leads to customer satisfaction would be said to be successful. Evaluating the performance of project is beneficial to both the stakeholders by enabling them to appraise the services received and to project manager by helping them to improve their services (Besner \& Hobbs, 2008). Project success relates to the end product's goals in terms of performance and fulfilling the technical requirements, as well as customer satisfaction. Successful projects also contributes to company's success in long term in terms of gaining a competitive advantages; enhancing company's reputation; increasing the market share; and reaching specified revenue and profits (Al-Tmeemy, 2011). Project manager whose personality profile was close to the ideal Project Manager's profile for a particular project type were more successful in impact on the customers, benefit to the organization and overall success (Malach et' al, 2009). This ultimately means that the project managers who understand the projects will be in a better position to satisfy the clients of the project and the stakeholders.

In a nutshell project success can be assessed on the basis of completion within scheduled time, completion within reasonable cost and within budget, quality achievement, meeting of technical requirement, project achieving user satisfaction and finally achievement of organizational objectives.

\subsection{Strength of Monitoring Team}

Providing support and strengthening of M\&E team is a sign of good governance. Providing support and strengthening of $M \& E$ team will also play a key role in ensuring that the M\&E team adds value to the organizations operations (Naidoo, 2011). A motivated team usually achieves high performance (Zaccaro et' al, 2002). This implies that the more a team is strengthened, the better the performance and value addition to the organization. This also applies to the monitoring and evaluation teams in project management. Interestingly Pretorius et' al (2012) observed that there was no significant association between the maturity of quality management practices in project management organizations and the results of the projects that they produce. Nevertheless it is the view of the researcher that managers should indeed aspire to achieve quality in all the aspects and processes, including quality monitoring team, so as to achieve project success.

The literature reviewed identifies the various aspects which are used in assessing the strength of monitoring team which is perceived to be one of the factors influencing project success. These aspects include: Financial availability, number of monitoring staff, monitoring staff skills, frequency of monitoring, stakeholders representation, Information systems (Use of technology), Power of M \& E Team and teamwork among the members (Naidoo, 2011; Ling et' al, 2009; Magondu, 2013; Hassan, 2013; Georgieva \& Allan, 2008; Gwadoya, 2012)

\subsection{M\&E Approach}

Another factor which has been conceptualized as having influence on project success and related to $M \& E$ is the approach used in monitoring and evaluating projects. In monitoring the project specifications, the monitoring team may check the progress of activities against the plan. They should review performance regularly and at the stipulated review points, and confirm the validity and relevance of the remainder of the plan. They may also be required to recommend adjustments to the plan if necessary in light of performance, changing circumstances, and new information, but remain on track and within the original terms of reference. The monitoring team should make sure that they use transparent, pre-agreed measurements when judging performance (Chapman, 2014).

Aritua et' al (2007) developed a model that recognizes that multi-projects are executed as a means of attaining some business objective and/or hybrid business and project objective as a means to enhance main business operations or service provision. Project success framework is a universal tool for achieving goals and objectives. Project success framework is also a context-specific tool for achieving objectives and Project success is a tool for achieving organizations strategic objectives (Cuellar, .2013). M\&E team may be a very important tool in ensuring that projects are being implemented within the confines of achieving business objectives. In order to achieve this value for the organization, the M\&E team should employ an approach or a combination of approaches which suits the organization and/or the projects being monitored and evaluated.

Several researchers have identified a number of $M \& E$ approaches that can be used in evaluating projects. Most of these approaches have a primary goal of ensuring that the project is in the right track in achieving the desired success for value creation. These approaches include basic research, accounting and certification, status assessment, effectiveness measurement, Objectives evaluation - value for money, Balanced Scorecard and Earned Value Analysis (Stem et al, 2005; Abdul-Rahman, Wang, \& Muhammad, 2011; Alotaibi, 2011; Mladenovic et' al, 2013; Alhyari et' al, 2013).

\subsection{Project Lifecycle Stage}

PMBOK (2001) and indeed several other researchers have simplified project lifecycle into four main stages which are project initiation, planning stage, execution stage and closing out. Each stage of project life cycle requires different effort from the management. Likewise each stage in the project life cycle requires different level of effort in terms of monitoring and evaluation effort.

Most of the literature reviewed asserts that during initiation stage, management effort in terms of monitoring and evaluation is minimal since the project is in the early stages. During the planning stage monitoring and evaluation effort of the project is higher than the initiating stage since the project is gaining some momentum. During execution stage the management effort in most aspects including monitoring and 
evaluation is at its maximum. The execution stage is the most risky stage where the probability of not achieving project success is at its peak due to numerous project activities. It is during this stage that the project M\&E team should be most active in monitoring and providing timely feedback. Finally during closing down the monitoring and evaluation just like other management activities is less intensified as compared to the execution stage. Most of the monitoring activities during this stage involves reporting on the project outcome and preparing for future projects (Kyriakopoulos, 2011; Chin, 2012; Pinto and Slevin, 1988; Müller and Turner, 2007; Khang and Moe, 2008).

\subsection{Political Influence on $M \& E$}

The political scene in Kenya is characterized by individualism and ethnicity (Okello, 2010). Economic and social inequalities are also a major concern in the Kenya's political scene (Muhula, 2009). When political institutions are weak then politicians can exploit fractionalization for their own benefit (Burgess et' al, 2013). The Kenyan constitution (2010) attempted to deal with some of these issues by introducing devolution, a system where the national resources are shared equitably across 47 regional governments called county governments. This means that many projects which were carried out at national level will be implemented at the county level. The concern is that, the politics of ethnicity, individualism and economic inequalities may also be devolving to the county governments and this may affect the project success in the specific county.

Burgess et' al, (2013) explains that, though many of Africa's ills have been blamed on ethnic favoritism among other factors, it has been surprisingly difficult to find concrete evidence of this behavior, mostly due to lack of data. This study will add to the existing data by collecting evidence on how political influence affects project monitoring and project success in Kenya. The political influence will be assessed on the basis of ethnicity, politicians individualism (number of sacred cow projects), and economic inequalities as perceived by the target respondents. This implies that this variable will be analyzed using qualitative techniques.

As provided for in the Kenya's constitution (2010), there are two categories of politicians in the county governments. These two categories are the members of county assembly, who are elected to represent smaller units called wards in the county government and the governor, who is elected to head the county government. These two categories of politicians are elected by the same people and may have different influences over the projects implemented. The analysis of this variable will take into consideration the two cadres of politicians.

\subsection{Management Support}

According to PMBOK, Project Management performs those processes that organize, manage, and lead the project team. The project team is comprised of the people with assigned roles and responsibilities for completing the project. The type and number of project team members can change frequently as the project progresses. "Project management organizations with mature human resource management practices produce more successful projects than project management organizations with less mature human resource management practices" (Pretorius et' al, 2012). Andersen (2006) in his research observed that managerial ability to deliver a project was found to be strongly related to the application of strong project management based on planning and cost control methodologies. Project impact can benefit from rich project communications, a factor which is less based on project management methodologies and more dependent upon the application of "softer" skills (Andersen, 2006).

There seems to be a consensus among the literature reviewed that management support plays a major role in achievement of project success. Literature reviewed points out several measures that can be used in assessing the management support to the project teams, including M\&E team. These measures include Communication, management Commitment, Leadership Style, managing politics, managing societal demands and Motivation (Muriithi \& Crawford, 2003; Marangu, 2012; Jetu \& Riedl, 2013; Atencio, 2012; Yong \& Mustaffa, 2012; Attarzadeh \& Ow, 2008; Georgieva \& Allan, 2008; Yang et' al, 2011).

Management support is a mediating variable in the relationship between monitoring and evaluation and the project success. According to Pequegnat et' al (1995) a mediating variable is the intervening variable that must change in order to see change in the dependent variable. On the other hand the moderating variable tends to interact in some fashion to alter the relationship between the dependent and the independent variable. Normally the mediating variable changes while the moderating variable does not. In some instances it is the one targeted for change in the intervention.

\section{Conceptual Framework}

On the basis of the review of literature as explained in the immediate previous sections, the conceptual framework is a combination of the various findings in literature which have been grouped and arranged to a framework which will guide this research in an attempt to provide a solution to the research problem. The conceptual framework is illustrated in Fig 2 below. 
Independent Variables

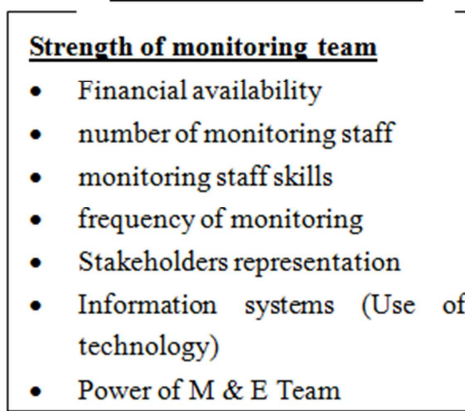

- $\quad$ Power of M \& E Team

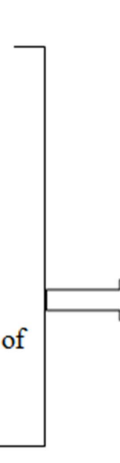

M \& E Approach

- Basic research

- accounting and certification

- status assessment

- effectiveness measurement

- Objectives evaluation

- Internal Audits

- Balanced Scorecard

- Earned Value Analysis

- Logframe matrix

\section{Project life cycle stage}

- initiation

- Planning

- execution

- closing down

\section{Political influence}

- Managing politics during M\&E $\underline{\text { Mediating Variables }}$

\section{Dependent Variables}

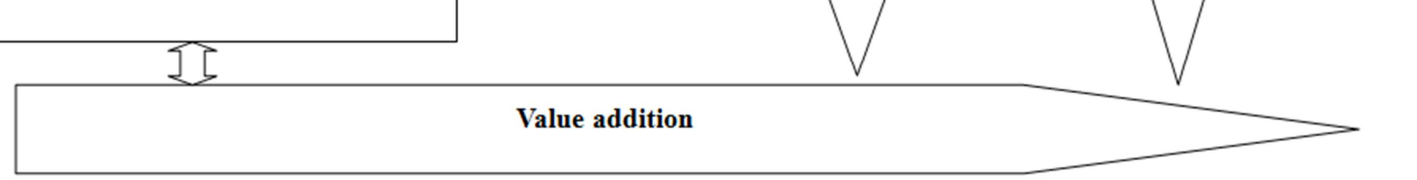

Fig. 2. Conceptual Framework.

The framework depicts the relationships between monitoring and evaluation and project success as mediated by management support. It is conceptualized that Effectiveness strength of monitoring team, approach used by M\&E team in evaluating projects, and the stage of project lifecycle will influence project success. On the other hand project success is dependent on the level of management support given to project monitoring and evaluation activity. The monitoring and evaluation activities, management support and project success are all geared towards achievement of value addition to the organization.

\section{References}

[1] Abdul-Rahman, H., Wang, C., \& Muhammad, N. A. B. (2011). Project performance monitoring methods used in Malaysia and perspectives of introducing EVA as a standard approach. Journal of Civil Engineering and Management, 17(3), 445-455.
[2] Al-Tmeemy, S. M. H. M., Abdul-Rahman, H., \& Harun, Z. (2011). Future criteria for success of building projects in Malaysia. International Journal of Project Management, 29(3), 337-348.

[3] Alhyari, S., Alazab, M., Venkatraman, S., Alazab, M. and Alazab, A. (2013) "Performance evaluation of e-government services using balanced scorecard: An empirical study in Jordan", Benchmarking: An International Journal, 20 (4) 512 536

[4] Alotaibi, M. (2011). Evaluation of contractor performance for pre-selection in the Kingdom of Saudi (Doctoral dissertation). Loughborough University, Leicestershire, UK.

[5] Andersen, E. S., Birchall, D., Jessen, A. S. and Money, A. H. (200). Exploring Project Success. Baltic Journal of Management, 1 (2) $127-147$

[6] Ara, A., \& Al-Mudimigh, A. S. (2011). The Role and Impact of Project Management in ERP project implementation life cycle. Global Journal of Computer Science and Technology, 11(5) 6-10. 
[7] Arancon, R. N. (Ed.). (1997). Environmentally Friendly Coconut and Coconut Products: Proceedings of the XXXIV COCOTECH Meeting, 14-18 July 1997, Manila, Philippines. Asian and Pacific Coconut Community.

[8] Aritua, B., Smith, N. J., \& Bower, D. (2009). Construction client multi-projects-A complex adaptive systems perspective. International Journal of Project Management, 27(1), 72-79.

[9] Asaka, C. N., Aila, F. O., Odera, O., \& Abongo, B. E. (2012) Projects selection and management implications in Kenyan local authorities. Asian Journal of Business and Management Sciences, 1 (10) 65-75

[10] Atencio, M. (2012). A critical success factors framework that includes leadership competencies for successful delivery of projects (Doctoral dissertation). University of Salford. Retrieved from Dissertations and Theses database. (http://usir.salford.ac.uk/30638/)

[11] Atieno, R. (2014). Policy Brief 014: The limits of success: The case of dairy sector in Kenya. Available from $\mathrm{http}: / /$ www.google.com/url? sa $=\mathrm{t} \& \mathrm{rct}=\mathrm{j} \& \mathrm{q}=\&$ esrc $=\mathrm{s} \&$ source $=$ web\&cd $=5 \&$ cad $=$ rja\&uact $=8 \&$ ved $=0$ CEoQFjAE \&url $=\mathrm{http} \% 3$ $\mathrm{A} \% 2 \mathrm{~F} \% 2 \mathrm{Fwww}$.future-agricultures.org $\% 2 \mathrm{Fw}$ orkshop-resourc es\%2Fdoc_download\%2F143-the-limits-of-success-the-case-o f-the-dairy-sector-in-kenya\&ei=jSF4U7uIKcjqPPHfgPgK\&us $\mathrm{g}=$ AFQjCNFnUMYnzJaiJeVjT1C0314oU1adxg\&bvm=bv.66 917471,d.bGE, Accessed 18-5-2014.

[12] Attarzadeh, I., \& Ow, S. H. (2008) Modern Project Management: Essential Skills and Techniques. Communications of the IBIMA 2, 1-9

[13] Azimi, R., Lee, S., AbouRizk, S. M., \& Alvanchi, A. (2011). A framework for an automated and integrated project monitoring and control system for steel fabrication projects. Automation in Construction, 20(1), 88-97.

[14] Babbie, Earl R. (2012) The practice of social research. Belmont, USA: Cengage Learning.

[15] Baker, B. N., Murphy, D. C. and Fisher, D. (1988). Factors affecting project success In: Cleland DI, King WR, editors. Project management handbook. (2nd ed.). New York: John Wiley.

[16] Baker, B. N., Murphy, D. C., \& Fisher, D. (2008). Factors affecting project success. Project Management Handbook, Second Edition, 902-919.

[17] Bamberger, Michael and Hewitt, Eleanor. World Bank Technical Paper no 53. (Washington, D.C.: 1986)

[18] Baron, R. M. and Kenny, D. A. (1986) "The Moderator-Mediator Variable Distinction in Social Psychological Research - Conceptual, Strategic, and Statistical Considerations", Journal of Personality and Social Psychology, Vol. 51(6), pp. 1173-1182

[19] Besner, C., \& Hobbs, B. (2008). Project management practice, generic or contextual: A reality check. Project Management Journal, 39(1), 16-33.

[20] Bewick, V., Cheek, L., \& Ball, J. (2003). Statistics review 8: Qualitative data-tests of association. Critical care, 8(1), 46.

[21] Bredillet, C. N. (2008). Exploring research in project management: Nine schools of project management research (part 4). Project Management Journal, 39(1), 2-6.
[22] Burgess, R., Jedwab, R., Miguel, E., \& Morjaria, A. (2013). The Value of Democracy: Evidence from Road Building in Kenya (No. w19398). National Bureau of Economic Research.

[23] Burke, R. (2013). Project management: planning and control techniques.

[24] Centre for Learning on Evaluation and Results (CLEAR) Initiative at Wits. (2013) Demand and Supply: Monitoring, Evaluation, and Performance Management Information and Services In Anglophone Sub-Saharan Africa, A Synthesis of Nine Studies. Johannesburg, South Africa: Graduate School of Public and Development Management, University of Witwatersrand.

[25] Chan APC, Scott D, Chan APL. Factors affecting the success of a construction project. J Construct Eng Manage 2004; 130(1):153-5.

[26] Chan, A. (2001). Framework for measuring success of construction projects.

[27] Chapman, A. "project management, tools, process, plans and project planning tips" available from http://www.businessballs.com/project.htm, accessed 8-3-2014.

[28] Cheng, M. Y., Hoang, N. D., Roy, A. F., \& Wu, Y. W. (2012). A novel time-depended evolutionary fuzzy SVM inference model for estimating construction project at completion. Engineering Applications of Artificial Intelligence, 25(4), 744-752.

[29] Cheruiyot, P. K., \& Kwasira, J. (2013). An assessment of devolving human resource function in Kenya: a case study of Nakuru County. International Journal of Human Resource Management.

[30] Chin, C. M. M. (2012). Development of a project management methodology for use in a university-industry collaborative research environment (Doctoral dissertation). University of Nottingham, Semenyih Selangor Darul Ehsan, Malaysia

[31] Creswell, J. W., \& Plano Clark, V. L. (2011). Designing and conducting mixed methods research (2nd ed.). Thousand Oaks, CA: Sage Publications, Inc.

[32] Cuellar, M. J. (2013). The Nature of Project Success.

[33] Cusworth, J. W., \& Franks, T. R. (2013). Managing projects in developing countries. Routledge.

[34] Dvir, D., 2005. Transferring projects to their final users: the effect of planning and preparations for commissioning on project success. International Journal of Project Management $23,257-265$.

[35] Georgieva, S., \& Allan, G. (2008). Best Practices in Project Management Through a Grounded Theory Lens. Electronic Journal of Business Research Methods, 6(1), 43-52

[36] Guide, A. (2001). PROJECT MANAGEMENT BODY OF KNOWLEDGE (PMBOK® GUIDE). In Project Management Institute.

[37] Gwadoya, R. A. (2012). Factors influencing effective implementation of monitoring and evaluation practices in donor funded projects in Kenya: a case of Turkana District (Masters dissertation). Kenyatta University, Nairobi, Kenya

[38] Hassan, A. I. (2013) An Investigation of Structural Capacity as a Component of Monitoring and Evaluation in Project Success of Road Construction Projects in Kenya. International Journal of Academic Research in Business and Social Sciences, 03 (08), $443-452$ 
[39] Hughes, S. W., Tippett, D. D., \& Thomas, W. K. (2004). Measuring Project Success in the Construction Industry. Engineering Management Journal, 16(3) 31-37.

[40] Hummelbrunner, R. (2010). Beyond Logframe: Critique, variations and alternatives. Beyond logframe; Using systems concepts in evaluation, 1 .

[41] Hwang, B. and Lim, E. (2013). "Critical Success Factors for Key Project Players and Objectives: Case Study of Singapore." J. Constr. Eng. Manage., 139(2), 204-215.

[42] Isaac, S., \& Navon, R. (2013). Can project monitoring and control be fully automated?. Construction Management and Economics, (ahead-of-print), 1-11.

[43] Ika, L. A. (2009). Project success as a topic in project management journals. Project Management Journal, 40(4), 6-19.

[44] Ika, L. A. (2012). Project management for development in Africa: why projects are failing and what can be done about it. Project Management Journal, 43(4), 27-41.

[45] Ika, L. A., Diallo, A., \& Thuillier, D. (2012). Critical success factors for World Bank projects: an empirical investigation. International Journal of Project Management, 30(1), 105-116.

[46] Ika, L. A., Diallo, A., \& Thuillier, D. (2010). Project management in the international development industry: the project coordinator's perspective. International Journal of Managing Projects in Business, 3(1), 61-93.

[47] Jetu, F. T., \& Riedl, R. (2013). Cultural values influencing project team success: An empirical investigation in Ethiopia. International Journal of Managing Projects in Business, 6(3), 425-456.

[48] Juli, T. (2010). Leadership principles for project success. CRC Press.

[49] Kahilu, D. (2010). Monitoring and evaluation report of "the impact of information and communication technology service (ICTs) among end users in the ministry of agriculture and cooperatives in Zambia". Journal of Development and Agricultural Economics, 3(7), 302-311

[50] Kantai, W. (2010). Lessons for Devolution: A Country Comparative Study in Devolution in Kenya, Prospects, Challenges and the Future. IEA Research Paper, (24).

[51] Kariungi, S. M. (2014). Determinants of Timely Completion of Projects in Kenya: A Case of Kenya Power and Lighting Company, Thika. ABC Journal of Advanced Research, 3(2), 9-19.

[52] Khang, D. B., \& Moe, T. L. (2008). Success criteria and factors for international development projects: A life-cycle-based framework. Project Management Journal, 39(1), 72-84.

[53] Kibebe, L. W., \& Mwirigi, P. W. (2014). Selected Factors Influencing Effective Implementation of Constituency Development Fund (CDF) Projects in Kimilili Constituency, Bungoma County, Kenya. International Journal of Science and Research, 3 (1), 44-48

[54] Kimando, L. N., Njogu, G. W., \& Kihoro, J. M. (2012). Factors Affecting the Success of Youth Enterprise Development Funded Projects in Kenya; A Survey of Kigumo District Muranga County. International Journal of Business \& Commerce, 1(10), 61-81.
[55] Kline P (1999) The handbook of psychological testing (2nd ed.) London: Routledge.

[56] Kontinen, T., \& Robinson-Moncada, S. (2014). Towards new practices of monitoring in World Vision Finland: Pathways of empowerment.

[57] Kothari, C. R. (2008). Research Methodology: Methods and Techniques. $\left(2^{\text {nd }} E d\right)$, Nairobi, Kenya: New Age International Publishers.

[58] Kyriakopoulos, G. L. (2011). Project Management (PM) Prosperity: A Second Half of the 20th Century Literature Review. Journal of Management and Sustainability, 1 (1), 64-81.

[59] Ling, F. Y. Y., Low, S. P., Wang, S. Q., \& Lim, H. H. (2009). Key project management practices affecting Singaporean firms' project performance in China. International Journal of Project Management, 27(1), 59-71.

[60] Magondu, A. (2013). Factors Influencing Implementation Of Monitoring And Evaluation In Hiv Research Projects, A Case Of Kenya Aids Vaccine Initiative (Kavi) (Masters dissertation). University of Nairobi, Kenya.

[61] Malach-Pines, A., Dvir, D., \& Sadeh, A. (2009). Project manager-project (PM-P) fit and project success. International Journal of Operations \& Production Management, 29(3), 268-291.

[62] Marangu, E. M. (2012). Factors influencing implementation of community based projects undertaken by the banking industry in Kenya. a case of Barclays Bank of Kenya (Masters dissertation). Kenyatta University, Nairobi,Kenya

[63] Mbeche, I. M. (2011). Critical success factors of industrial and commercial projects in Kenya. Operations Research Society of Eastern Africa Journal, 1(1), 93-108.

[64] Middleton, A. (2005). Logical Framework Analysis: A Planning Tool for Government Agencies, International Development Organizations, and Undergraduate Students. Undercurrent, 2(2), 41-47.

[65] Miller, G. J., \& Yang, K. (Eds.). (2007). Handbook of research methods in public administration. CRC press.

[66] Mladenovic, G., Vajdic, N., Wündsch, B., \& Salaj, A. T. (2013). Use of Key performance indicators for PPP transport projects to meet stakeholders' performance objectives. Built Environment Project and Asset Management, 3(2), 228-249.

[67] Martinez, D. E. (2011). The Logical Framework Approach in Non-governmental Organizations. University of Alberta

[68] Mono, O. R. (2013). Determinants of successful delivery of housing construction Projects in the Ministry of Housing in Nairobi, Kenya. Retrieved from: http://ir-library.ku.ac.ke/handle/123456789/6213

[69] Mugenda, Abel Gitau (2008) Social Science Research; Theories and principles. Nairobi, Kenya: Applied Research \& Training services.

[70] Muhula, R. (2009). Horizontal inequalities and ethno-regional politics in Kenya. Kenya Studies Review, 1(1), 85-105.

[71] Müller, R., \& Turner, R. (2007). The influence of project managers on project success criteria and project success by type of project. European Management Journal, 25(4), 298-309. 
[72] Muriithi, N., \& Crawford, L. (2003). Approaches to project management in Africa: implications for international development projects. International Journal of Project Management, 21(5), 309-319.

[73] Mwala F.V. (2012). Effect of project monitoring on implementation of economic stimulus projects in education sector within Nairobi County, Kenya (Masters dissertation). Kenyatta University, Nairobi, Kenya

[74] Myrick, D. (2013). A Logical Framework for Monitoring and Evaluation: A Pragmatic Approach to M\&E. Mediterranean Journal of Social Sciences, 4(14), 423-428

[75] Nachmias, David (1996) Research Methods in the social sciences, $5^{\text {th }}$ Edition. London, UK: St Martins Press Inc.

[76] Naidoo, I. A. (2011). The role of monitoring and evaluation in promoting good governance in South Africa: A case study of the Department of Social Development (Doctoral dissertation, University of Witwatersrand).

[77] Ochieng, F., Chepkuto, P., Tubey, R., \& Kuto, L. Y. (2012) Effectiveness of monitoring and evaluation of CDF projects in Kenya. A case of Ainamoi Constituency, 1(6), 186-194

[78] Okello, D. (2010). The dynamics of political change and transition: civil society, governance and the culture of politics in Kenya. In V. Coelho and B. V. Lieres (eds.), Mobilizing for Democracy: Citizen Action and the Politics of Public Participation pp.199-219.. London: Zed Books.

[79] Omari, A. O., Kaburi, S. N., \& Sewe, T. (2013, February). CHANGE DILEMMA: A CASE OF STRUCTURAL ADJUSTMENT THROUGH DEVOLUTION IN KENYA. In Scientific Conference Proceedings. 491-499

[80] Omari, E (2013) “Kenya's white elephants" Daily Nation $3^{\text {rd }}$ November 2013

[81] Ondari, P. O., and Gekara, J. M. (2013) "Factors influencing successful completion of roads projects in Kenya." International Journal of Social Sciences and Entrepreneurship $1(6), 26-48$.

[82] Papke-Shields, K. E., Beise, C., \& Quan, J. (2010). Do project managers practice what they preach, and does it matter to project success?. International Journal of Project Management, 28(7), 650-662.

[83] Pequegnat, W., Stover, E., \& Boyce, C. A. (1995). How to write a successful research grant application. A guide for social and behavioral scientists. New York, USA: Springer science + Business media

[84] Peterson, F., \& Fischer, M. (2009, April). Project Monitoring Methods Exploratory Case Analysis: Industry Responses. In Computing in Civil Engineering (2009) (pp. 105-114). ASCE.

[85] Pinto, J. K. and Slevin, D. P. (1988) Critical success factors across the project life cycle. Project Management Journal, 19(3):67-75.

[86] Pinto, J. K., \& Slevin, D. P. (1988). 20 Critical Success Factors in Effective Project implementation. Project management handbook, 479: 167-190.

[87] Pinto, J. K. (2000). Understanding the role of politics in successful project management. International Journal of Project Management, 18(2), 85-91.
[88] Prabhakar, G. P.(2008). What is Project Success: A Literature Review. International Journal of Business and Management, 3 (9), 1-10.

[89] Pretorius, S., Steyn, H., \& Jordaan, J. C. (2012). Project management maturity and project management success in the engineering and construction industries in Southern Africa. South African Journal of Industrial Engineering, 23(3), 1-12.

[90] Pretorius, S., Steyn, H., \& Jordaan, J. C. (2012). Project management maturity and project management success in the engineering and construction industries in Southern Africa. South African Journal of Industrial Engineering, 23(3), 1-12.

[91] Rasli, A. (2006). Data analysis and interpretation: A handbook for post graduate social sciences. Selangor Darul Ehsan, Malaysia: Percetakan Info Meditasi.

[92] Raymond, L., \& Bergeron, F. (2008). Project management information systems: An empirical study of their impact on project managers and project success. International Journal of Project Management, 26(2), 213-220.

[93] Republic of Kenya (RoK). (2010). Constitution of Kenya 2010.

[94] Reynolds, J. H., Thompson, W. L., \& Russell, B. (2011). Planning for success: identifying effective and efficient survey designs for monitoring. Biological Conservation, 144(5), 1278-1284.

[95] Shukla, P. (2008), Essentials of Marketing Research. Frederiksberg: Ventus Publishing.

[96] Sisk, T. (2003). History of project management. Berkely University.

[97] Stem, C., Margoluis, R., Salafsky, N., \& Brown, M. (2005). Monitoring and evaluation in conservation: a review of trends and approaches. Conservation Biology, 19(2), 295-309.

[98] UNICEF Guide for Monitoring and Evaluation - Making a Difference. http://preval.org/documentos/00473.pdf

[99] United Nations development programme (UNDP, 2002) evaluation office - Handbook on Monitoring and Evaluating for Results. New York, USA available from: http://web.undp.org/evaluation/documents/handbook/me-hand book.pdf

[100] Walliman, N (2005) Your Research Project, $2^{\text {nd }}$ Edition London, UK: Sage Publications

[101] Ward, L. J. (2010) "Analysis of the Koins for Kenya andSelf Reliant Agriculture Projects in Mnyenzeni" available from http://www.koinsforkenya.org/forms/Analysis-of-SRA-Project s.pdf, accessed 27-02-2014

[102] Warren, K. B. \& Susan C. B. (1991) Women, Technology, and International Development Ideologies: Analyzing Feminist Voices. In Gender at the Crossroads: Feminist Anthropology in the Postmodern Era. Micaela di Leonardo, ed. Berkeley: University of California Press.;278-311.

[103] World Bank (2007) "Monitoring and Evaluation: Tips for strengthening organizational capacity" Available from http://siteresources.worldbank.org/INTBELARUS/Resources/ M\&E.pdf, accessed 5-08-2014

[104] Yang, J., Shen, G. Q., Ho, M., Drew, D. S., \& Chan, A. P. (2009). Exploring critical success factors for stakeholder management in construction projects. Journal of civil engineering and management, 15(4), 337-348. 
[105] Yang, L. R., Huang, C. F., \& Wu, K. S. (2011). The association among project manager's leadership style, teamwork and project success. International journal of project management, 29(3), 258-267.

[106] Yong, Y. C., \& Mustaffa, N. E. (2012). Analysis of factors critical to construction project success in Malaysia. Engineering, Construction and Architectural Management, 19(5), 543-556.
[107] Young, T. (2007). The Handbook of Project Management: A Practical Guide to Effective Policies and Proced. Kogan Page Publishers.

[108] Zaccaro, S. J., Rittman, A. L., \& Marks, M. A. (2002). Team leadership. The Leadership Quarterly, 12(4), 451-483. 